\title{
Copper Status of Very Low Birth Weight Infants during the First 12 Months of Infancy ${ }^{1}$
}

\author{
MARY R. L'ABBÉ AND JAMES K. FRIEL \\ Nutrition Research Division, Food Directorate, Health Protection Branch, Health and Welfare Canada, Ottawa, \\ Canada K1A OL2 and Departments of Biochemistry and Pediatrics, Memorial University of Newfoundland, \\ St. John's, Newfoundland, Canada A1B $3 X 9$
}

\begin{abstract}
The $\mathrm{Cu}$ intake and status of 106 very low birth weight (VLBW) infants (birth weight $1152 \pm 251 \mathrm{~g}$, gestational age $29 \pm 3 \mathrm{wk}$, mean \pm SD) were determined approximately 1 mo before hospital discharge, at discharge (time 0 ), and at $3,6,9$, and 12 mo \pm 3 wk corrected for gestational age. Infants were fed either formula plus supplemental $\mathrm{Zn} / \mathrm{Cu}$ (SUPPL, $n=29$ ); formula plus placebo (PLAC, $n=26$ ); or a low birth weight formula (LBWF, $n=26$ ) or were breast-fed (BRMLK, $n=25$ ). Plasma $\mathrm{Cu}$ levels in the formula-fed infants increased significantly at each time period with no significant differences between feeding groups. Hair $\mathrm{Cu}$ was significantly higher in the SUPPL group compared to the PLAC, LBWF, and BRMLK groups at 3 and 6 mo. Erythrocyte $\mathrm{Cu}, \mathrm{Zn}$-superoxide dismutase (CuZnSOD) activity was lowest in the PLAC group. Cu intake was positively correlated with both hair $\mathrm{Cu}(r=0.291, p<0.0001)$ and erythrocyte CuZnSOD activity $(r=0.281, p<0.001)$ but not with plasma $\mathrm{Cu}$. An increasing number of formula-fed infants had very low CuZnSOD activity (less than 2 SD below mean) with increasing age $(n=1,2,8,11$, and 13 infants at times $0,3,6,9$, and $12 \mathrm{mo}$, respectively). At $12 \mathrm{mo}$, approximately one third of the formula-fed VLBW infants in this study had low $\mathrm{Cu}$ status as assessed by $\mathrm{CuZnSOD}$ activity. Infants with the lowest CuZnSOD activity were those with the largest weight gains from 0 to 6 mo and were observed in all formula-fed groups. Thus, these data suggest that in formula-fed infants erythrocyte $\mathrm{CuZnSOD}$ activity is a more appropriate indicator of $\mathrm{Cu}$ status in the VLBW infant than plasma $\mathrm{Cu}$ levels and that the fastest growing VLBW infants may be at risk for $\mathrm{Cu}$ deficiency. (Pediatr Res 32: 183-188, 1992)
\end{abstract}

\section{Abbreviations}

VLBW, very low birth weight

CuZnSOD, Cu,Zn-superoxide dismutase

VLBW infants $(<1500 \mathrm{~g})$ are particularly at risk for trace element deficiencies because of reduced tissue stores, especially in the liver, their rapid postnatal growth, and their less developed gastrointestinal tract. This is especially true for $\mathrm{Cu}$, as more than two thirds of the $\mathrm{Cu}$ in human fetal liver is accumulated during the last 10-12 wk of gestation (1). These limited stores increase the vulnerability of the VLBW infant to $\mathrm{Cu}$ deficiency (2), which

Received November 21, 1991; accepted March 11, 1992

Correspondence and reprint requests: Dr. Mary R. L'Abbé, Nutrition Research Division, Health and Welfare Canada, Banting Research Centre, Ross Avenue, Ottawa, Ontario CANADA K1A OL2

Supported by Health and Welfare Canada and Ross Laboratories.

'Publication No. 378 of the Bureau of Nutritional Sciences. is further compounded by their rapid postnatal growth. The net negative $\mathrm{Cu}$ balance of the VLBW infant, observed by several researchers (3-6), has been suggested to be due to the immaturity of their gastrointestinal tract, resulting in decreased resorption of endogenous losses (7).

$\mathrm{Cu}$ is an essential component of several enzymes including cytochrome $c$ oxidase, the terminal component of the electron transport chain that is ultimately responsible for the production of energy in the cell (8); CuZnSOD, which catalyzes the removal of the superoxide radical, thereby protecting cells from potentially harmful oxidizing effects (9); lysyl oxidase, which is involved in collagen cross-linking; and ferroxidases (including ceruloplasmin), which catalyze the oxidation of $\mathrm{Fe}^{2+}$ to $\mathrm{Fe}^{3+}(8)$. A decrease in the activity of this wide range of $\mathrm{Cu}$-requiring enzymes is probably responsible for the broad range of symptoms seen in $\mathrm{Cu}$ deficiency.

Serum $\mathrm{Cu}$ levels have traditionally been used to assess $\mathrm{Cu}$ status; however, in the VLBW infant the use of serum $\mathrm{Cu}$ levels to determine $\mathrm{Cu}$ status is complicated by a steady rise in serum $\mathrm{Cu}$ as the infant ages. This rise in serum $\mathrm{Cu}$ appears to be related to postconceptional age rather than postpartum age $(6,10)$ and has been reported to steadily increase until $4 \mathrm{mo}$ of age in the VLBW infant (6). Erythrocyte activity of trace element-requiring enzymes, on the other hand, is a good indicator of long-term trace element status and has several advantages for assessing status (11). Erythrocytes are readily obtained and, because of their long half-life, enzyme activity is not responsive to shortterm fluctuations in trace element intakes. Thus, the purpose of the present experiment was to determine the $\mathrm{Cu}$ status of a group of VLBW infants and assess various measures of $\mathrm{Cu}$ status, namely $\mathrm{Cu}$ intake, plasma $\mathrm{Cu}$, hair $\mathrm{Cu}$, and erythrocyte $\mathrm{Cu}$ ZnSOD activity. In addition, a second objective was to determine if a $\mathrm{Zn}$ and $\mathrm{Cu}$ supplement would improve the $\mathrm{Cu}$ status of the VLBW infant using these various measures of $\mathrm{Cu}$ status. Infants were fed either formula with supplemental $\mathrm{Zn}+\mathrm{Cu}$, formula plus placebo, a low birth weight formula, or breast milk.

\section{MATERIALS AND METHODS}

Subjects. One hundred six infants $<1500 \mathrm{~g}$ birth weight (birth weight $1152 \pm 251 \mathrm{~g}$; gestational age $29 \pm 3 \mathrm{wk}$; mean \pm SD) were recruited for this study from the neonatal intensive care units of the Dr. Charles A. Janeway Child Health Centre, the Grace General Hospital, and St. Clare's Mercy Hospital in St. John's, Newfoundland. The study was conducted prospectively in double-blind fashion and was approved by the Faculty of Medicine Human Investigations Committee. Infants were excluded from the study if they suffered from severe bronchopulmonary dysplasia that required more than 2 wk of oxygen therapy, had hydrocephalus, liver dysfunction, or any congenital malformations. The $\mathrm{Fe}$ and $\mathrm{Zn}$ status of these infants has been previously reported $(12,13)$. Approximately $85 \%$ of parents of eligible infants approached for this study consented to enroll 
their infants. Of the 106 infants recruited, 84 were formula-fed and 25 were breast-fed. Two formula-fed infants passed away during their hospital stay and one infant was removed to a hospital out of province, leaving 81 formula-fed infants for whom data were available at discharge.

The gestational age of each infant was taken from the last menstrual period of the mother and was also determined by the Dubowitz method (14). If there was a discrepancy of more than 2 wk between the two assessments, the latter was used. Size for gestational age was appropriate if the birth weight fell within 2 $\mathrm{SD}$ of weight for gestational age according to the growth curves of Lubchenco (15).

All infants received uniform management as established in the neonatal intensive care unit, and formula-fed infants were fed a premature special care formula containing $3.5 \mathrm{~kJ} / \mathrm{mL}(24 \mathrm{cal} /$ fluid ounce) until they could tolerate a formula containing $3 \mathrm{~kJ} /$ $\mathrm{mL}$ (20 cal/fluid ounce). At that time (approximately $1 \mathrm{mo}$ before discharge, weight $1850 \pm 106 \mathrm{~g}$; gestational age $36 \pm 3$ wk), infants were assigned using random number tables to receive either 1) infant formula with whey and supplemental $\mathrm{Zn} / \mathrm{Cu}$ drops (SUPPL; $n=29$ ); 2) infant formula with whey and water drops (PLAC; $n=26$ ); or 3) an experimental low birth weight formula (LBWF; $n=26$ ). A group of infants whose mothers chose to breast-feed were also monitored and served as a reference group (BRMLK; $n=25$ ). Some of these infants received special care formula until breast-feeding was fully established. The supplemental $\mathrm{Zn} / \mathrm{Cu}$ drops [containing $76.5 \mathrm{mmol} / \mathrm{L}(5$ $\mathrm{mg} / \mathrm{mL}) \mathrm{Zn}$ and $15.7 \mathrm{mmol} / \mathrm{L}(1 \mathrm{mg} / \mathrm{mL}) \mathrm{Cu}$ ] were prepared by adding U.S.P. grade $\mathrm{Zn}$ and $\mathrm{CuSO}_{4}$ to deionized water that was autoclaved along with plain deionized water before being added to unmarked $15-\mathrm{mL}$ amber dropper bottles. Formula feedings in hospital were prepared in the formula room so that the nurses did not know to which group an infant was assigned. All infants were fed ad libitum. At discharge, parents were provided with the $15-\mathrm{mL}$ amber dropper bottles and were instructed to add 32 drops ( $1 \mathrm{~mL}$ ) to each 32-ounce can of formula before preparing individual feedings. Infants fed LBWF did not have any drops added to their formula. All formulas were iron-fortified and were donated by Ross Laboratories (Columbus, $\mathrm{OH}$ ) in 32-ounce, ready-to-feed cans. Final nutrient compositions of the formulas are provided in Table 1.

Infants in the study were discharged from hospital at a mean weight of $2533 \pm 290 \mathrm{~g}$. There were no significant differences in body weight, gestational age, $\mathrm{Hb}$, or ferritin in the different feeding groups at discharge. Study formula and drops were

Table 1. Composition of test formulas (per $L)^{*}$

\begin{tabular}{lcc}
\hline & SUPPL/PLAC & LBWF \\
\hline Protein (g) & 15.7 & 17.3 \\
Fat (g) & 36 & 37 \\
Carbohydrate (g) & 73 & 71 \\
Energy [kcals (MJ)] & $670(2.8)$ & $670(2.8)$ \\
Ca [mg (mmol)] & $490(12.2)$ & $680(17.0)$ \\
P [mg (mmol)] & $345(11.4)$ & $416(13.4)$ \\
Na [mg (mmol)] & $230(10.0)$ & $230(10.0)$ \\
K [mg (mmol)] & $750(19.2)$ & $1000(25.6)$ \\
Vitamin A (IU) & 3200 & 4000 \\
Vitamin D (IU) & 400 & 550 \\
Vitamin E (IU) & 20 & 30 \\
Vitamin C [mg $(\mu \mathrm{mol})]$ & $100(568)$ & $200(1136)$ \\
Vitamin B1 [mg $(\mu \mathrm{mol})]$ & $0.65(2.2)$ & $1.00(3.3)$ \\
Vitamin B2 [mg $(\mu \mathrm{mol})]$ & $1.0(2.7)$ & $1.5(4.0)$ \\
Vitamin B6 [mg $(\mu \mathrm{mol})]$ & $0.52(3.1)$ & $0.68(4.0)$ \\
Fe [mg $(\mu \mathrm{mol})]$ & $13(233)$ & $13(233)$ \\
Zn [mg $(\mu \mathrm{mol})]$ & $11.7 / 6.7(179 / 102)$ & $9(138)$ \\
Cu [mg $(\mu \mathrm{mol})]$ & $1.8 / 0.76(28 / 12)$ & $0.8(13)$ \\
\hline
\end{tabular}

* Values are as reported on product label. Molar values are given in parentheses and have been calculated. provided for 5 mo after discharge from hospital. After that time, parents were responsible for purchasing their own formula. All subjects were told to restrict food intake to formula only during the first $3 \mathrm{mo}$ in compliance with recommendations of the Canadian Pediatric Society (16) and Health and Welfare Canada (17).

Sample collection and analysis. Data were collected in the hospital at study entry (approximately 1 mo before hospital discharge) (time P) and at hospital discharge (time 0). After discharge, all infants were monitored at the Provincial Perinatal Follow-up Clinic at $3,6,9$, and $12 \mathrm{mo} \pm 3 \mathrm{wk}$ corrected for gestationat age. Some infants did not attend all scheduled visits; therefore, values were not available for all infants at each sampling time. At each visit possible, a blood sample, a hair sample, a 3-d dietary record, and body weight measurements were collected by a research assistant or by hospital staff. Three-day dietary records were completed by nursing staff in hospital and by parents or guardians before each visit. Each record was verified for accuracy and completeness by a trained research assistant. Unclothed body weights for the preterm infants in hospital and at follow-up clinics were obtained with a calibrated spring balance using the mean of three measurements. For the breast-fed infants, sampling was begun at $3 \mathrm{mo}$, and only dietary information, body weight measurements, and hair samples were collected.

Heparinized blood samples $(0.5-1 \mathrm{~mL})$ were obtained from a heel or finger prick. Samples were centrifuged and separated, and plasma was frozen at $-20^{\circ} \mathrm{C}$ until analysis. Erythrocytes, were washed, lysed, stabilized with glutathione $(2 \mathrm{mM}$ reduced glutathione in $10 \mathrm{mM}$ potassium phosphate buffer, $\mathrm{pH} 7.0$ ), and shipped with dry ice to Ottawa for enzymatic assays.

All storage and analytical containers were acid-washed and only purified water was used $(>18 \mathrm{M} \Omega$, Barnstead Purification Systems). Plasma and hair $\mathrm{Cu}$ analyses were performed on a Perkin-Elmer (Norwalk, CT) 2380 Atomic Absorption Spectrophotometer with HGA-300 graphite furnace (18). The accuracy of the $\mathrm{Cu}$ method was assessed using quality control sera (Dade, Cation-Cal, Baxter Diagnostics Co., Mississauga, Ontario, Canada).

Erythrocyte $\mathrm{CuZnSOD}(\mathrm{EC} \cdot 1.15 .1 .1)$ activity was determined using an automated xanthine, xanthine oxidase, cytochrome $c$ assay (9) and expressed per $\mathrm{mg}$ of $\mathrm{Hb}$ in the lysate. $\mathrm{Hb}$ in the erythrocyte lysate was determined using an automated modification of the method of Beutler (19). Quality control was assayed using pooled rat erythrocytes that had been washed, lysed, and prepared as described above and stored at $-85^{\circ} \mathrm{C}$.

Dietary data were coded and converted into grams using a database available at the Department of Biochemistry, Memorial University of Newfoundland. Mean daily intakes of $\mathrm{Cu}$ were calculated using a modified database consisting of $\mathrm{Cu}$ values obtained from company product information, food composition tables, and the literature (20).

One-way analysis of variance was done at each sampling time to assess differences due to gender, size for gestational age, and effects due to feeding group. Two-way analysis of variance was done to determine effects of both feeding group and time. Pearson correlation coefficients were determined to assess relationships between $\mathrm{Cu}$ intake, plasma $\mathrm{Cu}$, hair $\mathrm{Cu}$, and erythrocyte CuZnSOD activity. All computations were done using the CSS Statistical software package (StatSoft, Tulsa, OK). Significant differences between means were determined by the least significant difference method at the $p<0.05$ level of significance.

\section{RESULTS}

Body weights of the VLBW infants in this study were not significantly different among the different formula groups at any sampling time, although the BRMLK-fed infants had lower body weight at $3 \mathrm{mo}$. By $6 \mathrm{mo}$, there were no differences in body weight between any groups. 
No significant differences due to gender or size for gestational age were seen in dietary $\mathrm{Cu}$, plasma $\mathrm{Cu}$, hair $\mathrm{Cu}$, or erythrocyte CuZnSOD activity (data not shown); thus, data for all infants were pooled for both gender and for size for gestational age.

The pooled $\mathrm{Cu}$ intake and the changes in $\mathrm{Cu}$ status of the VLBW infants during the 1st year are shown in Table 2. For the breast-fed infants, only dietary intake, body weight, and hair $\mathrm{Cu}$ were determined. Dietary $\mathrm{Cu}$ intake in these VLBW infants ranged from 500 to $900 \mu \mathrm{g} / \mathrm{d}$, with the highest intake seen at 3 mo. This intake then leveled off at 550 to $650 \mu \mathrm{g} / \mathrm{d}$ for the final 6 to 12 mo. When expressed per $\mathrm{kg}$ body weight, intakes were highest in hospital (time P) and then declined thereafter for the next year. Plasma $\mathrm{Cu}$ in formula-fed infants, in contrast with dietary intakes, significantly rose throughout the study. Hair $\mathrm{Cu}$ was fairly constant from study entry (time $\mathrm{P}$ ) to hospital discharge (time 0) and from 9 to $12 \mathrm{mo}$. The highest levels of hair $\mathrm{Cu}$ were found at $3 \mathrm{mo}$, followed by those at $6 \mathrm{mo}$, which corresponded to the times at which $\mathrm{Cu}$ intakes were the highest. Erythrocyte CuZnSOD activity in formula-fed infants was highest at the start of the study at times $\mathrm{P}$ and 0 and then gradually decreased at 3 , 6,9 , and $12 \mathrm{mo}$.

The $\mathrm{Cu}$ intakes of the VLBW infants receiving the different feeding treatments are shown in Table $3 . \mathrm{Cu}$ intake $(\mu \mathrm{g} / \mathrm{kg} / \mathrm{d})$ of the SUPPL group was greater than that of the PLAC group at 0 and $3 \mathrm{mo}$. Infants receiving the LBWF had a $\mathrm{Cu}$ intake slightly above that of the PLAC group but less than that of the SUPPL group. At $3 \mathrm{mo}$, the lowest calculated $\mathrm{Cu}$ intake was seen in the BRMLK-fed group. After 6 mo, there were no significant differences in $\mathrm{Cu}$ intake $(\mu \mathrm{g} / \mathrm{kg} / \mathrm{d})$ between any groups.

The effects of the different feeding treatments on $\mathrm{Cu}$ status over time are shown in Tables 4 to 6 . Plasma $\mathrm{Cu}$ levels significantly increased at each time interval, but the differences in $\mathrm{Cu}$ intake between the different formula-fed groups were not reflected in differences in plasma $\mathrm{Cu}$ levels at times $\mathrm{P}, 0,3$, and 6 mo (Table 4). The rise in plasma $\mathrm{Cu}$ over time was similar in all groups. Hair $\mathrm{Cu}$ levels (Table 5) were highest in the SUPPL group compared to all other feeding groups at 3 and $6 \mathrm{mo}$, with elevated hair $\mathrm{Cu}$ levels being displayed in the time period just after the highest $\mathrm{Cu}$ intakes. This elevation in hair $\mathrm{Cu}$ in the SUPPL group was no longer evident at 9 and 12 mo.

Erythrocyte CuZnSOD activity declined in all formula-fed groups over time (Table 6 ). There were no significant differences between feeding groups at each time period; however, pooled over the entire study period, the lowest overall CuZnSOD activity was seen in the PLAC group $(90 \pm 37 \mathrm{U} / \mathrm{mg} \mathrm{Hb})(p<0.05)$ compared to the SUPPL and LBWF groups ( $97 \pm 40$ and $100 \pm$ $32 \mathrm{U} / \mathrm{mg} \mathrm{Hb}$, respectively). During the course of the study, there were an increasing number of infants with low erythrocyte $\mathrm{CuZnSOD}$ activity $(<50 \mathrm{U} / \mathrm{mg} \mathrm{Hb})$; data for these infants are given in Table 7. Infants with low erythrocyte CuZnSOD activity were seen in all formula-fed groups $(n=3,4$, and 6 infants from the SUPPL, PLAC, and LBWF groups, respectively), and low activity was confined to these 13 infants. Erythrocyte CuZnSOD activity in these infants was progressively lower at each time interval, whereas in the other infants activity remained constant at $110 \pm 26 \mathrm{U} / \mathrm{mg} \mathrm{Hb}$ throughout the study. VLBW infants with the lowest erythrocyte $\mathrm{CuZnSOD}$ activity were those infants with the higher growth rates and lower $\mathrm{Cu}$ intake per $\mathrm{kg}$ body weight during the first 9 mo (Table 7).

Correlation coefficients for dietary $\mathrm{Cu}(\mu \mathrm{g} / \mathrm{kg} / \mathrm{d})$, plasma $\mathrm{Cu}$, hair $\mathrm{Cu}$, and erythrocyte CuZnSOD activity were calculated for time 0 on. Dietary $\mathrm{Cu}$ was positively correlated with both hair $\mathrm{Cu}(r=0.291, p<0.0001)$ and CuZnSOD activity $(r=0.281, p$ $<0.001$ ). In contrast, plasma $\mathrm{Cu}$ was negatively correlated to both dietary $\mathrm{Cu}(r=-0.526, p<0.0001)$ and erythrocyte CuZnSOD $(r=-0.284, p<0.0001)$.

\section{DISCUSSION}

Both the Canadian Pediatric Society (21) and the American Academy of Pediatrics (22) have recommended that formula-fed low birth weight infants receive $90 \mu \mathrm{g} \mathrm{Cu} / 100 \mathrm{kcal}$ (equivalent to $108 \mu \mathrm{g} \mathrm{Cu} / \mathrm{kg} / \mathrm{d}$ ) to avoid $\mathrm{Cu}$ depletion, as compared to the recommendation for full-term infants of $60 \mu \mathrm{g} \mathrm{Cu} / 100 \mathrm{kcal}(23)$. Recommendations as high as 100 to $120 \mu \mathrm{g} \mathrm{Cu} / \mathrm{kg} / \mathrm{d}$ for VLBW infants have also been made (24), inasmuch as biochemical evidence of $\mathrm{Cu}$ deficiency was seen in five of 14 formula-fed VLBW infants fed $80 \mu \mathrm{g} \mathrm{Cu} / \mathrm{kg} / \mathrm{d}$ (25). Symptoms observed in some of the infants included low neutrophil counts, $\mathrm{Hb}$, red blood cell counts, and reticulocyte counts. The $\mathrm{Cu}$ requirement of the VLBW infant is thought to be somewhat higher than that of the full-term infant because fetal liver $\mathrm{Cu}$ levels increase from 2.5 to $9 \mathrm{mg}$ during the last $12 \mathrm{wk}$ of gestation (1) and this much greater store of $\mathrm{Cu}$ would not be available to the VLBW infant for use.

$\mathrm{Cu}$ deficiency has been reported in formula-fed infants, with the majority of cases being in low birth weight or premature infants (for review see Ref. 26). The median age for presentation of $\mathrm{Cu}$ deficiency in full-term infants was $8.3 \mathrm{mo}(5-18 \mathrm{mo})$, whereas it was $3 \mathrm{mo}$ in VLBW infants (26). This difference in the onset of $\mathrm{Cu}$ deficiency is probably a consequence of the reduced $\mathrm{Cu}$ stores of the VLBW infant. In addition, the bioavailability of $\mathrm{Cu}$ from cow's milk-based infant formula is less than that of breast milk. In the premature infant, retentions of around $10 \%$ have been reported for $\mathrm{Cu}$ from formula as compared to $50 \%$ from human milk $(5,27)$. Preterm infants fed formula providing approximately $500 \mu \mathrm{g} \mathrm{Cu} / \mathrm{L}$ were in negative (or just barely positive) $\mathrm{Cu}$ balance for $4 \mathrm{wk}$, but even those in positive balance did not approach normal liver in utero accretion rates (5). Thus, the formula-fed VLBW infant is at an increased risk for Cu deficiency.

Serum $\mathrm{Cu}$ levels are the most common method used to assess $\mathrm{Cu}$ status; however, in the VLBW infant a steady rise in serum $\mathrm{Cu}$ has been observed $(6,28,29)$. This rise in serum $\mathrm{Cu}$ is seen

Table 2. Changes in Cu status over time in VLBW infant*

\begin{tabular}{|c|c|c|c|c|c|c|c|}
\hline & \multicolumn{6}{|c|}{ Time $(\mathrm{mo}) \dagger$} & \multirow[b]{2}{*}{$p$ value $\neq$} \\
\hline & $\mathrm{P}$ & 0 & 3 & 6 & 9 & 12 & \\
\hline Weight (kg) & $1.9 \pm 0.1^{\mathrm{a}}$ & $2.5 \pm 0.3^{b}$ & $5.2 \pm 0.9^{c}$ & $6.8 \pm 1.0^{\mathrm{d}}$ & $8.0 \pm 1.2^{\mathrm{e}}$ & $8.6 \pm 1.2^{\mathrm{f}}$ & $<0.00001$ \\
\hline Diet $\mathrm{Cu}(\mu \mathrm{g} / \mathrm{d})$ & $512 \pm 84^{a}$ & $518 \pm 200^{a}$ & $864 \pm 392^{c}$ & $577 \pm 223^{a, b}$ & $552 \pm 225^{a}$ & $647 \pm 269^{b}$ & $<0.00001$ \\
\hline Diet $\mathrm{Cu}(\mu \mathrm{g} / \mathrm{kg} / \mathrm{d})$ & $276 \pm 46^{d}$ & $205 \pm 81^{\mathrm{c}}$ & $170 \pm 83^{b}$ & $86 \pm 31^{a}$ & $72 \pm 30^{\mathrm{a}}$ & $77 \pm 35^{a}$ & $<0.00001$ \\
\hline Plasma Cu $(\mu \mathrm{mol} / \mathrm{L}) \S$ & $8.1 \pm 2.5^{\mathrm{a}}$ & $10.2 \pm 3.0^{\mathrm{b}}$ & $16.1 \pm 4.7^{\mathrm{c}}$ & $18.9 \pm 4.2^{\mathrm{d}}$ & $20.4 \pm 5.8^{e}$ & $22.4 \pm 4.1^{f}$ & $<0.00001$ \\
\hline Hair Cu $(\mu \mathrm{g} / \mathrm{g}) \|$ & $16.8 \pm 13.0^{\mathrm{a}}$ & $15.9 \pm 12.2^{\mathrm{a}}$ & $46.2 \pm 15.9^{c}$ & $25.7 \pm 14.3^{b}$ & $19.8 \pm 9.3^{\mathrm{a}, \mathrm{b}}$ & $19.4 \pm 10.9^{\mathrm{a}}$ & $<0.00001$ \\
\hline RBC CuZnSOD (U/mg Hb $) \S$ & $111 \pm 39^{c}$ & $116 \pm 26^{c}$ & $102 \pm 29^{b, c}$ & $90 \pm 36^{a, b}$ & $81 \pm 32^{\mathrm{a}}$ & $85 \pm 44^{\mathrm{a}}$ & $<0.0001$ \\
\hline
\end{tabular}

* Values are means $\pm \mathrm{SD}$; means on the same row with different superscripts are significantly different $(p<0.05)$.

$\uparrow$ Data collection times were at study entry (time P), which was approximately 1 mo before hospital discharge (time 0 ); mean weight at time 0 was $2553 \pm 290 \mathrm{~g}$. All other times refer to age in mo corrected for gestational age.

$\$$ Determined by analysis of variance.

$\S$ Determined in formula-fed infants only.

|| Hair samples were not available for breast-fed infants at times $\mathrm{P}$ and 0 . 
Table 3. Dietary intake of Cu by different feeding groups*

\begin{tabular}{|c|c|c|c|c|}
\hline \multirow[b]{2}{*}{ Time } & \multicolumn{4}{|c|}{ Feeding group $\ddagger$} \\
\hline & SUPPL & PLAC & LBWF & BRMLK \\
\hline \multicolumn{5}{|c|}{$\mu \mathrm{g} / \mathrm{d}$} \\
\hline$P$ & $473 \pm 65(26)^{a}$ & $513 \pm 61(26)^{a, b}$ & $547 \pm 104(27)^{\mathrm{b}}$ & ND \\
\hline 0 & $752 \pm 127(29)^{\mathrm{b}}$ & $367 \pm 73(27)^{\mathrm{a}}$ & $415 \pm 83(26)^{a}$ & ND \\
\hline 3 & $1329 \pm 304(24)^{c}$ & $664 \pm 109(22)^{b}$ & $695 \pm 165(22)^{\mathrm{b}}$ & $350 \pm 55(6)^{a}$ \\
\hline 6 & $664 \pm 210(25)^{\mathrm{b}}$ & $547 \pm 197(17)^{\mathrm{a}, \mathrm{b}}$ & $495 \pm 246(20)^{a}$ & $573 \pm 200(11)^{a, b}$ \\
\hline 9 & $595 \pm 226(22)^{\mathrm{a}, \mathrm{b}}$ & $550 \pm 248(18)^{\mathrm{a}, \mathrm{b}}$ & $473 \pm 164(22)^{\mathrm{a}}$ & $671 \pm 281(7)^{b}$ \\
\hline 12 & $737 \pm 333(19)^{\mathrm{b}}$ & $669 \pm 277(16)^{\mathrm{a}, \mathrm{b}}$ & $545 \pm 184(22)^{a}$ & $667 \pm 235(9)^{\mathrm{a}, \mathrm{b}}$ \\
\hline \multicolumn{5}{|c|}{$\mu \mathrm{g} / \mathrm{kg} / \mathrm{d}$} \\
\hline $\mathrm{P}$ & $256 \pm 33(26)^{a}$ & $274 \pm 37(26)^{a}$ & $299 \pm 56(26)^{b}$ & ND \\
\hline 0 & $302 \pm 49(28)^{c}$ & $139 \pm 24(26)^{a}$ & $166 \pm 26(26)^{b}$ & ND \\
\hline 3 & $269 \pm 64(21)^{c}$ & $125 \pm 27(20)^{b}$ & $142 \pm 50(22)^{b}$ & $72 \pm 19(6)^{a}$ \\
\hline 6 & $98 \pm 34(23)$ & $76 \pm 26(14)$ & $80 \pm 30(17)$ & $80 \pm 23(9)$ \\
\hline 9 & $78 \pm 29(19)$ & $72 \pm 37(13)$ & $62 \pm 22(20)$ & $83 \pm 43(6)$ \\
\hline 12 & $89 \pm 44(16)$ & $69 \pm 31(13)$ & $69 \pm 29(18)$ & $81 \pm 30(6)$ \\
\hline
\end{tabular}

* Values are means $\pm \mathrm{SD}(n)$; means on the same row with different superscripts are significantly different $(p<0.05)$. ND, not determined.

$\dagger$ All infants except the BRMLK group were fed premature formula (Special Care, Ross Laboratories) from birth to time P, which was approximately $1 \mathrm{mo}$ before hospital discharge (time 0); mean weight at time 0 was $2553 \pm 290 \mathrm{~g}$. All other times refer to age in mo corrected for gestational age.

$¥$ See text for full details of feeding groups.

Table 4. Plasma Cu ( $\mu$ mol/L) of VLBW infants fed different diets*

\begin{tabular}{cccc}
\hline & \multicolumn{3}{c}{ Feeding group } \\
\cline { 2 - 4 } Time & SUPPL & PLAC & LBWF \\
\hline $\mathrm{P}$ & $7.9 \pm 2.1(26)$ & $8.3 \pm 2.7(27)$ & $8.1 \pm 2.8(24)$ \\
0 & $9.6 \pm 2.9(28)$ & $10.0 \pm 2.9(25)$ & $11.0 \pm 3.1(24)$ \\
3 & $16.0 \pm 5.0(22)$ & $17.3 \pm 4.8(21)$ & $14.9 \pm 4.1(18)$ \\
6 & $18.3 \pm 3.9(25)$ & $18.4 \pm 4.3(22)$ & $20.2 \pm 4.3(18)$ \\
9 & $18.3 \pm 5.5(23)^{\mathrm{a}}$ & $20.9 \pm 6.2(19)^{\mathrm{a}, \mathrm{b}}$ & $22.5 \pm 5.3(18)^{\mathrm{b}}$ \\
12 & $20.9 \pm 3.1(17)^{\mathrm{a}}$ & $22.7 \pm 3.7(19)^{\mathrm{a}, \mathrm{b}}$ & $23.7 \pm 5.1(17)^{\mathrm{b}}$ \\
\hline
\end{tabular}

* Values are means $\pm \mathrm{SD}(n)$; means on the same row with different superscripts are significantly different $(p<0.05)$; times and feeding groups are the same as in Table 3. Plasma $\mathrm{Cu}$ was not determined in the BRMLK group.

even when the infant is in net negative $\mathrm{Cu}$ balance $(3,30)$. It appears that serum $\mathrm{Cu}$ in the VLBW infant reflects the capacity of the immature liver to synthesize ceruloplasmin, not $\mathrm{Cu}$ status, thus rendering it a poor indicator of $\mathrm{Cu}$ status (31). The very low plasma $\mathrm{Cu}$ levels in the normal neonate are thought to increase slowly toward normal adult levels during the first 3 mo of postnatal life (32). The results of the present study demonstrate that this is a much slower and longer process in the VLBW infant: plasma $\mathrm{Cu}$ levels continue to increase for the 1st year of postnatal life and beyond $3 \mathrm{mo}$, similar to term infants levels, they are higher than the normal adult values of $15.7 \mu \mathrm{mol} / \mathrm{L}$ $(100 \mu \mathrm{g} / \mathrm{dL})$ that we see in our laboratory (33).
Erythrocyte $\mathrm{CuZnSOD}$ is a good indicator of $\mathrm{Cu}$ status in adults and, in contrast with serum $\mathrm{Cu}$, it is not affected by such physiologic factors as estrogen levels (33) and responds to changes in $\mathrm{Cu}$ status before any differences in serum $\mathrm{Cu}$ or ceruloplasmin occur $(8,34,35)$. There is little information on the use of erythrocyte CuZnSOD activity to assess $\mathrm{Cu}$ status in VLBW infants, and it is not known whether it rapidly increases along with plasma $\mathrm{Cu}$ levels. A good correlation between erythrocyte $\mathrm{CuZnSOD}$ and plasma $\mathrm{Cu}$ levels was seen in eight $\mathrm{Cu}$-deficient full-term infants (mean age $14 \mathrm{mo}$ ) before and after $120 \mathrm{~d} \mathrm{Cu}$ supplementation, and these authors suggested that erythrocyte CuZnSOD activity is a good measure of $\mathrm{Cu}$ status (36). These infants, however, were beyond the period of the rapid rise in plasma $\mathrm{Cu}$ that occurs in infancy. The results of the present study demonstrate that erythrocyte CuZnSOD activity in the VLBW infant, in contrast with plasma Cu levels, did not increase dramatically during the 1st year, but rather, activity decreased by about $25 \%$ during this time period. Whether this decrease in $\mathrm{CuZnSOD}$ activity reflects nonoptimum $\mathrm{Cu}$ status or whether it is also a physiologic response cannot be determined with certainty from this study. However, several pieces of evidence suggest that some of these VLBW infants may have suboptimal $\mathrm{Cu}$ status as indicated by their erythrocyte CuZnSOD activity. CuZnSOD activity tended to be lower in the PLAC group compared to the SUPPL or LBWF groups. In addition, those infants with the lowest CuZnSOD activity $(<50 \mathrm{U} / \mathrm{mg} \mathrm{Hb})$ had a higher growth rate during the first 6 mo of the study compared to the other infants $(p<0.002)$ and subsequently had lower $\mathrm{Cu}$ intakes per $\mathrm{kg}$ body weight $(87 \pm 45$ versus $125 \pm 82 \mu \mathrm{g} / \mathrm{kg} / \mathrm{d}, p$

Table 5. Hair $C u(\mu \mathrm{g} / \mathrm{g})$ of $V L B W$ infants fed different diets*

\begin{tabular}{cllcc}
\hline & \multicolumn{3}{c}{ Feeding group } \\
\cline { 2 - 5 } Time & \multicolumn{1}{c}{ SUPPL } & \multicolumn{1}{c}{ PLAC } & LBWF & BRMLK \\
\hline $\mathrm{P}$ & $12.6 \pm 4.2(7)$ & $14.3 \pm 9.8(6)$ & $24.2 \pm 19.8(6)$ & ND \\
0 & $14.7 \pm 5.5(9)$ & $13.4 \pm 9.3(7)$ & $20.5 \pm 20.8(6)$ & ND \\
3 & $66.0 \pm 0(7)^{\mathrm{d}}$ & $56.0 \pm 0(10)^{\mathrm{c}}$ & $37.0 \pm 10.3(11)^{\mathrm{b}}$ & $26.7 \pm 6.0(7)^{\mathrm{a}}$ \\
6 & $39.9 \pm 11.0(10)^{\mathrm{b}}$ & $17.8 \pm 14.2(10)^{\mathrm{a}}$ & $18.2 \pm 8.1(9)^{\mathrm{a}}$ & $27.0 \pm 0(4)^{\mathrm{a}}$ \\
9 & $18.6 \pm 8.1(16)^{\mathrm{a}, \mathrm{b}}$ & $20.6 \pm 7.1(13)^{\mathrm{a}, \mathrm{b}}$ & $17.6 \pm 11.7(14)^{\mathrm{a}}$ & $25.4 \pm 9.3(7)^{\mathrm{b}}$ \\
12 & $21.3 \pm 15.9(13)^{\mathrm{b}}$ & $21.1 \pm 6.4(12)^{\mathrm{b}}$ & $20.7 \pm 10.2(16)^{\mathrm{a}, \mathrm{b}}$ & $12.8 \pm 6.5(10)^{\mathrm{a}}$ \\
\hline
\end{tabular}

* Values are means $\pm \mathrm{SD}(n)$; means on the same row with different superscripts are significantly different $(p<0.05)$; ND, not determined. Times and feeding groups are the same as in Table 3 . 
Table 6. Erythrocyte CuZnSOD activity $(\mathrm{U} / \mathrm{mg} \mathrm{Hb})$ of $V L B W$ infants fed different diets*

\begin{tabular}{cccc}
\hline & \multicolumn{3}{c}{ Feeding group } \\
\cline { 2 - 4 } Time & SUPPL & PLAC & LBWF \\
\hline P & $123 \pm 53(9)$ & $97 \pm 32(9)$ & $114 \pm 15(5)$ \\
0 & $122 \pm 17(8)$ & $108 \pm 32(11)$ & $123 \pm 25(5)$ \\
3 & $99 \pm 32(11)$ & $101 \pm 33(9)$ & $112 \pm 17(8)$ \\
6 & $82 \pm 37(12)$ & $85 \pm 38(11)$ & $109 \pm 31(7)$ \\
9 & $75 \pm 31(13)$ & $74 \pm 36(11)$ & $93 \pm 29(10)$ \\
12 & $97 \pm 49(10)$ & $80 \pm 46(11)$ & $80 \pm 41(13)$ \\
\hline
\end{tabular}

* Values are means $\pm \mathrm{SD}(n)$; times and feeding groups are the same as in Table 3. Erythrocyte CuZnSOD was not determined in the BRMLK group.

Table 7. Characteristics of VLBW infants with low erythrocyte $\mathrm{CuZnSOD}$ activity $(<50 \mathrm{U} / \mathrm{mg} \mathrm{Hb})$

\begin{tabular}{|c|c|c|c|c|}
\hline Parameter & Time & $\begin{array}{c}\text { Low SOD* } \dagger \\
(<50 \mathrm{U} / \mathrm{mg} \mathrm{Hb})\end{array}$ & $\begin{array}{c}\text { Normal SOD } \dagger \\
(110 \pm 26 \\
\mathrm{U} / \mathrm{mg} \mathrm{Hb})\end{array}$ & $p$ value \\
\hline $\begin{array}{c}\text { Erythrocyte SOD } \\
(\mathrm{U} / \mathrm{mg} \mathrm{Hb})\end{array}$ & $\begin{array}{r}0 \\
3 \\
6 \\
9 \\
12\end{array}$ & $\begin{array}{l}43(1) \\
43 \pm 5(2) \\
41 \pm 6(8) \\
41 \pm 9(11) \\
38 \pm 10(13)\end{array}$ & $\begin{array}{r}119 \pm 21(24) \\
108 \pm 23(28) \\
110 \pm 21(22) \\
99 \pm 19(24) \\
114 \pm 29(21)\end{array}$ & $<0.001$ \\
\hline Diet $\mathrm{Cu}(\mu \mathrm{g} / \mathrm{d})$ & $\begin{array}{r}0 \\
3 \\
6 \\
9 \\
12\end{array}$ & $\begin{array}{c}500(1) \\
900 \pm 283(2) \\
517 \pm 204(8) \\
567 \pm 296(9) \\
636 \pm 266(11)\end{array}$ & $\begin{array}{l}509 \pm 211(23) \\
900 \pm 399(22) \\
624 \pm 254(17) \\
496 \pm 213(21) \\
540 \pm 135(15)\end{array}$ & NS \\
\hline $\begin{array}{l}\text { Diet } \mathrm{Cu}(\mu \mathrm{g} / \\
\mathrm{kg} / \mathrm{d})\end{array}$ & $\begin{array}{r}0 \\
3 \\
6 \\
9 \\
12\end{array}$ & $\begin{array}{c}168(1) \\
161 \pm 81(2) \\
73 \pm 30(6) \\
75 \pm 38(7) \\
82 \pm 33(9)\end{array}$ & $\begin{array}{r}194 \pm 80(21) \\
172 \pm 88(20) \\
92 \pm 32(14) \\
68 \pm 31(18) \\
63 \pm 26(14)\end{array}$ & $<0.03$ \\
\hline Body weight $(\mathrm{kg})$ & $\begin{array}{r}0 \\
3 \\
6 \\
9 \\
12\end{array}$ & $\begin{array}{c}2.97(1) \\
5.89 \pm 1.21(2) \\
7.27 \pm 0.32(9) \\
8.18 \pm 0.44(8) \\
8.59 \pm 1.02(9)\end{array}$ & $\begin{array}{l}2.58 \pm 0.25(21) \\
5.50 \pm 1.16(24) \\
6.67 \pm 1.20(18) \\
7.90 \pm 1.57(21) \\
8.60 \pm 1.68(18)\end{array}$ & $<0.002$ \\
\hline
\end{tabular}

\section{* Less than 2 SD below the normal range.}

$\dagger$ Values are means $\pm \mathrm{SD}(n)$.

$<0.03)$, although total $\mathrm{Cu}$ intakes $(\mu \mathrm{g} / \mathrm{d})$ were not significantly different. Finally, for those infants with low CuZnSOD activity, the activity was progressively lower at each sampling time, with the majority first displaying low CuZnSOD activity at 6 mo. Excluding the infants with low CuZnSOD activity from the data in Table 2, erythrocyte CuZnSOD activity for the infants remained constant throughout the study at $110 \pm 26 \mathrm{U} / \mathrm{mg} \mathrm{Hb}$.

The results of this study confirm the results of others $(37,38)$ : dietary supplements of $\mathrm{Cu}$ do not accelerate or improve the increase in plasma $\mathrm{Cu}$ seen in VLBW infants. Hillman et al. (37) have shown that an increase in formula $\mathrm{Cu}$ from 40 to $167 \mu \mathrm{g}$ / $\mathrm{dL}$ for $8 \mathrm{wk}$ did not result in an elevation in serum $\mathrm{Cu}$ or ceruloplasmin, nor did a supplement of $500 \mu \mathrm{g} \mathrm{Cu} / \mathrm{d}$ for $4 \mathrm{mo}$ increase serum $\mathrm{Cu}$ in VLBW infants (38). These authors have suggested that, had the supplement lasted longer, differences may have been seen. However, in the study reported here, supplements were given for $6 \mathrm{mo}$ (time $\mathrm{P}$ to $5 \mathrm{mo}$ ), and, even with this extended supplementation period, plasma $\mathrm{Cu}$ levels did not increase. Both hair $\mathrm{Cu}$ and to a smaller degree erythrocyte $\mathrm{CuZnSOD}$ activity increased with $\mathrm{Cu}$ supplementation. Hair $\mathrm{Cu}$ levels increased at 3 mo and were more than doubled by 6 mo. This large increase was no longer evident after the supplements were discontinued. The large elevation in hair $\mathrm{Cu}$ levels reflected $\mathrm{Cu}$ intakes, with these increases evident later than at the start of the supplements. This is to be expected because hair mineral levels are known to reflect dietary intakes retrospectively (20). $\mathrm{Cu}$ supplementation had only a small effect on erythrocyte CuZnSOD activity, although this was not unexpected if the activity was already saturated in most infants.

Even though one group of infants also received $\mathrm{Zn}$ in the supplement, it is unlikely that the $\mathrm{Zn}$ supplement adversely affected their $\mathrm{Cu}$ status. In a previous study with adult subjects, we found that a ratio of $\mathrm{Zn}$ to $\mathrm{Cu}$ of at least 25 to 1 was needed before any decrease in erythrocyte CuZnSOD activity was observed (34).

In conclusion, these data demonstrate that erythrocyte $\mathrm{Cu}$ ZnSOD activity in the VLBW infant does not show the physiologic 3-fold increase during the 1st year that is observed with plasma $\mathrm{Cu}$ levels. The only parameters that were positively associated with dietary $\mathrm{Cu}$ intake were erythrocyte $\mathrm{CuZnSOD}$ activity and hair $\mathrm{Cu}$ levels. Thus, we suggest that erythrocyte $\mathrm{CuZnSOD}$ activity is a more appropriate indicator of $\mathrm{Cu}$ status in the VLBW infant than plasma $\mathrm{Cu}$ levels. Using erythrocyte $\mathrm{CuZnSOD}$ activity to assess $\mathrm{Cu}$ status, the results of this study suggest that up to one third of the formula-fed VLBW infants in the present study may have had suboptimal $\mathrm{Cu}$ status between 6 mo and $1 \mathrm{y}$. Low hair $\mathrm{Cu}$ levels in the breast-fed infants at 12 mo were also noted in this study. Further study, including $\mathrm{CuZnSOD}$ data, would be required to more fully assess the $\mathrm{Cu}$ status of the breast-fed infants. Six mo to 1 y also coincides with the time during which both formula-fed and breast-fed infants were switched to cow's milk containing approximately $0.1 \mathrm{mg}$ $\mathrm{Cu} / \mathrm{L}$, which is much lower than the $\mathrm{Cu}$ content of the infant formula. In the VLBW infant, the use of $\mathrm{Cu}$ supplements or a formula with supplemental $\mathrm{Cu}$ for longer than 6 mo may be beneficial.

Acknowledgments. The authors thank Craig Skinner and Keith Trick for their technical assistance and the staff of the neonatal intensive care units of the Dr. Charles A. Janeway Child Health Centre, Grace General Hospital, and St. Clare's Mercy Hospital in St. John's, Newfoundland for their support. The authors are especially grateful to the parents of the subjects for their dedicated participation in the study.

\section{REFERENCES}

1. Widdowson EM, Dauncey J, Shaw JCL 1974 Trace elements in foetal and early postnatal development. Proc Nutr Soc 33:275-284

2. Paterson CR, Burns J 1988 Copper deficiency in infancy. J Clin Biochem Nutr 4:175-190

3. Dauncey MJ, Shaw JCL, Urman J 1977 The absorption and retention of magnesium, zinc, and copper by low birth weight infants fed pasteurized human breast milk. Pediatr Res 11:991-997

4. Cavell PA, Widdowson EM 1964 Intakes and excretions of iron, copper, and zinc in the neonatal period. Arch Dis Child 39:496-501

5. Mendelson RA, Bryan MH, Anderson GH 1983 Trace mineral balances in preterm infants fed their own mother's milk. J Pediatr Gastroenterol Nutr 2:256-261

6. Tyrala EE, Manser JI, Brodsky NL, Tran N, Kotwall M, Friehling L 1985 Distribution of copper in the serum of the parenterally fed premature infant. J Pediatr 106:295-298

7. Ehrenkranz RA, Gettner PA, Nelli CM, Sherwonit EA, Williams JE, Ting BTG, Janghorbani M 1989 Zinc and copper nutritional studies in very low birth weight infants: comparison of stable isotopic extrinsic tag and chemical balance methods. Pediatr Res 26:298-307

8. L'Abbé MR, Fischer PWF 1984 The effects of high dietary zinc and copper deficiency on the activity of copper-requiring metalloenzymes in the growing rat. J Nutr 114:813-822

9. L'Abbé MR, Fischer PWF 1986 An automated method for the determination of $\mathrm{Cu}, \mathrm{Zn}$-superoxide dismutase in plasma and erythrocytes using an $\mathrm{ABA}$ 200 discrete analyzer. Clin Biochem 19:175-178

10. Hillman LS 1981 Serial serum copper concentrations in premature and SGA infants during the first 3 months of life. J Pediatr 98:305-308

11. L'Abbé MR, Collins MW, Trick KD, Laffey PJ 1992 Glutathione peroxidase activity in a healthy Canadian population. Effects of age, smoking and drinking habits, exercise and oral contraceptive use. Trace Elem Med 9:4553

12. Friel JK, Andrews WL, Matthew JD, Long DR, Cornel AM, Cox M, Skinner CT 1990 Iron status of very-low-birth-weight infants during the first 15 months of infancy. Can Med Assoc J 143:733-737 
13. Friel JK, Andrews WL, Matthew JD, Cornel AM, Cox M 1990 Zinc supplementation improves locomotor development. Pediatr Res 27:243A(abstr 1442)

14. Dubowitz LM, Dubowitz V, Goldberg C 1970 Clinical assessment of gestational age in the newborn infant. J Pediatr 77:1-16

15. Lubchenco LO, Hansman C, Dressler M, Boyd E 1963 lntrauterine growth as estimated from liveborn birthweight data at 24 to 42 weeks of gestation. Pediatr 32:793-800

16. Canadian Paediatric Society, Nutrition Committee 1979 Infant feeding. Can J Public Health 70:376-385

17. Health and Welfare Canada, Health Promotion Directorate 1986 Feeding Babies. Supply and Services Canada, Ottawa

18. Friel JK, Ngyuen CD 1986 Dry- and wet-ashing techniques compared in analyses for zinc, copper, manganese and iron in hair. Clin Chem 32:739742

19. Beutler E 1975 Red Cell Metabolism. A Manual of Biochemical Methods, 2nd Ed, Grune \& Stratton, New York, pp 11-12

20. Friel JK, Gibson RS, Balassa R, Watts JL 1984 A comparison of the zinc, copper and manganese status of very low birth weight pre-term and fullterm infants during the first twelve months. Acta Paediatr Scand 73:596601

21. Canadian Paediatric Society, Nutrition Committee 1981 Feeding the lowbirthweight infant. Can Med Assoc J 124:1301-1311

22. American Academy of Pediatrics, Committee on Nutrition 1985 Nutritional needs of low-birth-weight infants. Pediatrics 75:976-986

23. Health and Welfare Canada 1990 Nutrition Recommendations. The Report of the Scientific Review Committee. Supply and Services Canada, Ottawa, pp $157-159$

24. Hambidge KM 1989 Trace element requirements in premature infants. In: Lebenthal E (ed) Textbook of Gastroenterology and Nutrition in Infancy, 2nd Ed. Raven Press, New York, pp 393-401

25. Manser JI, Crawford CS, Tyrala EE, Brodsky NL, Grover WD 1980 Serum copper concentrations in sick and well preterm infants. J Pediatr 97:795799
26. Shaw JCL 1988 Copper deficiency and non-accidental injury. Arch Dis Child 63:448-455

27. Tyrala EE 1986 Zinc and copper balances in preterm infants. Pediatr 77:513517

28. Halliday HL, Lappin TRJ, McMaster D, Patterson CC 1985 Copper and the preterm infant. Arch Dis Child 60:1105-1106

29. Sutton AM, Harvie A, Cockburn F, Farquharson J, Logan RW 1985 Copper deficiency in the preterm infant of very low birthweight. Four cases and a reference range for plasma copper. Arch Dis Child 60:644-651

30. Shulman RJ 1989 Zinc and copper balance studies in infants receiving total parenteral nutrition. Am J Clin Nutr 49:879-883

31. Hillman LS 1982 Copper supplementation in premature infants. [reply] $\mathbf{J}$ Pediatr 100:511

32. Greene HL, Hambidge KM, Schanler R, Tsang RC 1988 Guidelines for the use of vitamins, trace elements, calcium, magnesium, and phosphorus in infants and children receiving total parenteral nutrition: report of the Subcommittee on Pediatric Parenteral Nutrient Requirements from the Committee on Clinical Practice Issues of the American Society for Clinical mutrition. Am J Clin Nutr 48:1324-1342

33. Fischer PWF, L'Abbé MR, Giroux A 1990 Effects of age, smoking, drinking, exercise and estrogen use on indices of copper status in healthy adults. Nutr Res 10:1081-1090

34. Fischer PWF, Giroux A, L'Abbé MR 1984 Effect of zinc supplementation on copper status in adult man. Am J Clin Nutr 40:743-746

35. Reiser S, Smith Jr JC, Mertz W, Holbrook JT, Scholfield DJ, Powell AS, Canfield WK, Canary JJ 1985 Indices of copper status in humans consuming a typical American diet containing either fructose or starch. Am J Clin Nutr 42:242-251

36. Uauy R, Castillo-Duran C, Fisberg M, Fernandez N, Valenzuela A 1985 Red cell superoxide dismutase activity as an index of human copper nutrition. Am J Clin Nutr 115:1650-1655

37. Hillman LS, Martin L, Fiore B 1981 Effect of oral copper supplementation on serum copper and ceruloplasmin concentrations in premature infants. $J$ Pediatr 98:311-313

38. Manser JI, Tran NN, Kotwal M, Hall L 1982 Copper supplementation in premature infants. J Pediatr 100:511 